\title{
Uveitis as a presenting feature of chronic sarcoidosis
}

\author{
G. Rizzato*, M. Angi**, P. Fraioli*, L. Montemurro*, E. Pilotto**, A. Tommasini+
}

Uveitis as a presenting feature of chronic sarcoidosis. G. Rizzato, M. Angi, P. Fraioli, L. Montemurro, E. Pilotto, A. Tommasini. CERS Journals Ltd 1996.

ABSTRACT: Uveitis is often a manifestation of sarcoidosis. Less well-recognized, however, is the development of uveitis several years before the diagnosis of systemic sarcoidosis. The possibility that presentation of uveitis is a marker for the chronicity of sarcoidosis has never been investigated. The aim of this work was to evaluate, in a Caucasian population, the epidemiology of uveitis as the primary manifestation of sarcoidosis with long-term follow-up, and the relationship of uveitis to the chronicity of sarcoidosis.

The records of 1,156 Caucasian patients with histologically proven sarcoidosis, first seen in the period 1976-1992, were reviewed. In patients in whom uveitis was the primary feature of sarcoidosis, the following parameters were identified: systemic manifestations; time interval between the diagnosis of uveitis and sarcoidosis; therapy; the evolution of chest radiographic image over time; chronicity; the relationship between sarcoidosis and uveitis; and, finally, status in October 1994.

In nine patients, uveitis was the reason for seeking medical treatment, resulting in the discovery of systemic sarcoidosis, which was then found to be chronic in 7 out of 9 cases. In an additional eight patients, uveitis preceded the diagnosis of systemic sarcoidosis by 1-11 yrs, and yet most subjects had systemic manifestations that went unrecognized during this time period, with chest radiograph at the time of diagnosis suggesting a long-standing chronic disease. Thus, uveitis appeared to be the primary manifestation of sarcoidosis in 17 of the 1,156 patients studied $(1.5 \%)$.

In conclusion, any uveitis of unknown origin may be due to sarcoidosis, although its systemic manifestations may not occur for up to $11 \mathrm{yrs}$. Uveitis patients need a very long-term follow-up, including periodic diagnostic tests for systemic sarcoidosis. Furthermore, when uveitis precedes the systemic symptoms and diagnosis of sarcoidosis by more than one year, it may be regarded as a marker of the chronicity of sarcoidosis.

Eur Respir J., 1996, 9, 1201-1205.
* Sarcoid Clinic, Medical Division Vergani, Niguarda Hospital, Milan, Italy. **Institute of Ophthalmology, Padua University, Padua, Italy. +Pneumology Division, USL-21, Padua, Italy.

Correspondence: G. Rizzato

Via Juvara 9

20129 Milan

Italy

Keywords: Chronic sarcoidosis epidemiology

eye

ocular sarcoidosis

sarcoidosis

uveitis

Received: November 171995

Accepted after revision February 51996
Ocular involvement in sarcoidosis is common both at the initial presentation and during the follow-up of the disease [1-21], and appears more frequently in Negroes than in Caucasians $[13,15,16]$. Less well-recognized is the fact that ocular involvement may precede the detectable systemic signs of sarcoidosis by several years.

It was only in 1988 that FOSTER [22] described eight patients in whom uveitis preceded the systemic manifestations of sarcoidosis by as much as 4 yrs. In a prospective study of 283 black and Caucasian uveitis patients, first seen at the Massachusetts Eye Infirmary, Boston, biopsy-proven systemic manifestations of sarcoidosis were discovered in six subjects. However, in an additional eight patients, such manifestations developed during the subsequent 4 year follow-up, with an interval from the onset of uveitis to diagnosis of sarcoidosis ranging 9 months to 4 yrs (average 2.2 yrs). Foster [22] concluded that uveitis may precede the subtlest diagnostic manifestations of sarcoidosis by up to 4 yrs. It is possible that a longer follow-up of these patients could have demonstrated additional cases. No information is given regarding further follow-up of chronicity.

One year later, Rотноу et al. [23] reviewed a group of 121 consecutive patients ( 69 whites and 52 blacks) with biopsy-proven sarcoidosis, who visited the sarcoidosis clinic of the University Hospital in Amsterdam. Fifteen patients had first consulted an ophthalmologist, with the final diagnosis of sarcoidosis not established until after their referral to a pneumologist. Moreover, in nine patients, the final diagnosis was only confirmed more than $1 \mathrm{yr}$ after the initial diagnosis of uveitis. No information is given regarding longer-term follow-up.

To our knowledge, there are no reports of this kind in a totally Caucasian population. The aim of the present study was to evaluate with long-term follow-up the prevalence of uveitis as the primary manifestation of sarcoidosis, and to establish the relationship between uveitis and the chronicity of sarcoidosis in a Caucasian population

\section{Patients and methods}

The records of 1,156 patients with histologically proven sarcoidosis were reviewed: 1) 618 patients were first seen in the Sarcoidosis Clinic of Niguarda Hospital, Milan, in the period October 1978-October 1992. Nearly all were also referred for a routine ophthalmic examination at the same hospital; and 2) 538 patients were first seen in the Lung Department or in the Internal Medicine Institute 
of Padua University in the period October 1980-October 1992, and referred to the Institute of Ophthalmology of the same university for the routine ophthalmic visit of patients with sarcoidosis.

October 31, 1992 was arbitrarily chosen as the final date for enrolment into the study, in order to have a follow-up of at least 2 months.

The ophthalmic examination consisted of: visual activity; Schirmer I test determination; applanation tonometry; a thorough slit-lamp examination of the conjunctiva and anterior segment; evaluation of the trabecular meshwork, vitreous base and peripheral retina with a scleral depressor-equipped contact lens, and of the posterior retina by indirect and direct ophthalmoscopy. Fluorangiography was performed in the presence of the chorioretinal lesions. Methodological details of each test have been described previously [10]. The diagnostic criteria for uveitis were those described by HoGAN et al. [24].

The work-up parameters for sarcoidosis included: chest radiograph; serum angiotensin-converting enzyme; pulmonary volumes; and transfer factor of the lung for carbon monoxide $\left(T_{\mathrm{L}}, \mathrm{CO}\right)$ in all patients; and ${ }^{67} \mathrm{Ga}$ lung scan; bronchoalveolar lavage (BAL) fluid examination; perfusion lung scan; calcaemia and calciuria, in most patients [25]. Hypercalciuria was recorded when at least two determinants were over $300 \mathrm{mg} \cdot 24 \mathrm{~h}^{-1}$ [26].

The 22 patients for whom uveitis was the primary reason for having sought medical advice were included in the present study, and form the basis of this report. All other known causes of uveitis were reasonably excluded in all of the above patients, based on results of the appropriate clinical and laboratory differential diagnostic tests. In particular, the following forms of uveitis were excluded: Behçet's disease; Reiter's syndrome; ankylosing spondylitis; juvenile rheumatoid arthritis; Herpes simplex or cytomegalovirus infection; syphilis; tuberculosis; toxoplasmosis; birdshot retinopathy; Harada's syndrome; presumed ocular histoplasmosis; recurrent multifocal choroiditis; candida; and pseudouveitis.

The follow-up of the above patients was reviewed to identify: 1) the systemic manifestations of sarcoidosis at presentation; 2) the time interval between the diagnosis of uveitis and the appearance of other sarcoid manifestations (pulmonary and/or extrapulmonary); 3) the relationship between sarcoidosis and uveitis in individual cases; 4) the choice and duration of therapy; 5) the evolution of the chest radiographic image over time; and 6) the chronicity of the disease.

\section{Results}

Nine patients were identified who had sought medical advice for uveitis with the subsequent discovery of coexisting asymptomatic, unrecognized systemic manifestations of sarcoidosis. In an additional 13 patients, uveitis

Table 1. - Presentation with uveitis and other systemic sarcoid manifestations

\begin{tabular}{|c|c|c|c|c|c|c|c|c|c|c|}
\hline \multirow{2}{*}{$\begin{array}{l}\mathrm{Pt} \\
\text { No. }\end{array}$} & \multirow{2}{*}{ Sex } & \multirow{2}{*}{$\begin{array}{l}\text { Age } \\
\text { yrs }\end{array}$} & \multirow[t]{2}{*}{ Uveitis } & \multirow[t]{2}{*}{ CXR } & \multirow{2}{*}{$\begin{array}{l}\text { Other manifestations } \\
\text { at presentation }\end{array}$} & \multirow[t]{2}{*}{ Biopsy } & \multirow{2}{*}{$\begin{array}{l}\text { Therapy } \\
\text { prednisone } \\
\text { months }\end{array}$} & \multicolumn{3}{|c|}{ Follow-up after diagnosis } \\
\hline & & & & & & & & Yrs & Eyes & Others \\
\hline 1 & $\mathrm{M}$ & 22 & $\begin{array}{l}\text { Posterior, } \\
\text { bilateral, } \\
\text { subacute }\end{array}$ & I & - & Kveim test & $10^{*}$ & 4 & No symptoms & $\begin{array}{c}\text { Stage II-VC } 76 \% \\
\Downarrow \\
\text { Regression after } \\
\text { prednisone therapy } \\
\text { to Stage 0 }\end{array}$ \\
\hline 2 & $\mathrm{~F}$ & 22 & $\begin{array}{l}\text { Anterior, } \\
\text { left, acute }\end{array}$ & II & $\begin{array}{l}\text { Bilateral parotid } \\
\text { gland enlargement, } \\
\text { Panda sign (Heerfordt's } \\
\text { syndrome) } \\
\text { Liver profile: } \\
\text { ALT } 56 \mathrm{U} \cdot \mathrm{L}^{-1} \text {, } \\
\text { AST } 72 \mathrm{U} \cdot \mathrm{L}^{-1} \text {, } \\
\gamma \text {-GT } 120 \mathrm{u} \cdot \mathrm{L}^{-1}\end{array}$ & Transbronchial & 14 & 2.5 & No symptoms & Stage III chronic \\
\hline 3 & $\mathrm{~F}$ & 61 & $\begin{array}{l}\text { Intermediate, } \\
\text { bilateral, } \\
\text { subacute }\end{array}$ & I & $\begin{array}{l}\text { Hypercalciuria } \\
\left(462 \mathrm{mg} \cdot 24 \mathrm{~h}^{-1}\right)\end{array}$ & $\begin{array}{l}\text { Scalene } \\
\text { lymph node }\end{array}$ & 30 & 4 & No symptoms & Stage I chronic \\
\hline 4 & M & 57 & $\begin{array}{l}\text { Anterior, } \\
\text { left, subacute }\end{array}$ & II & $\begin{array}{l}\text { Bilateral parotid } \\
\text { gland enlargement } \\
\text { (Heerfordt's syndrome) }\end{array}$ & $\begin{array}{l}\text { Left parotid } \\
\text { gland }\end{array}$ & 24 & 2 & No symptoms & Stage II chronic \\
\hline 5 & $\mathrm{M}$ & 25 & $\begin{array}{l}\text { Posterior, } \\
\text { bilateral }\end{array}$ & I & Conjunctiva & $\begin{array}{l}\text { 1. Transbronchial } \\
\text { 2. Conjunctiva }\end{array}$ & al $2^{\#}$ & 2 & No symptoms & Stage I chronic \\
\hline 6 & $\mathrm{~F}$ & 54 & $\begin{array}{l}\text { Anterior, } \\
\text { bilateral }\end{array}$ & I & - & Mediastinoscopy & y 3 & 2 & No symptoms & $\begin{array}{l}\text { Stage } \mathrm{I} \rightarrow 0 \\
\text { VC } 99 \%\end{array}$ \\
\hline 7 & $\mathrm{~F}$ & 63 & $\begin{array}{l}\text { Anterior } \\
\text { bilateral }\end{array}$ & II & - & Transbronchial & 19 & 4 & No symptoms & Stage II chronic \\
\hline 8 & $\mathrm{~F}$ & 54 & $\begin{array}{l}\text { Anterior, } \\
\text { bilateral }\end{array}$ & I & - & Transbronchial & 6 & 2 & $\begin{array}{l}\text { Chronic } \\
\text { uveitis }\end{array}$ & Stage $\mathrm{I} \rightarrow 0$ \\
\hline 9 & $\mathrm{~F}$ & 50 & $\begin{array}{l}\text { Anterior, } \\
\text { intermediate, } \\
\text { bilateral }\end{array}$ & I & Skin lesions & Transbronchial & 6 & 6 & $\begin{array}{l}\text { Posterior, } \\
\text { bilateral } \\
\text { cataract }\end{array}$ & Stage II chronic \\
\hline
\end{tabular}

*: effectively treated by cryotherapy (prednisone given 2 yrs later for the pulmonary impairment); \#: effectively treated by laser therapy. Pt: patients; M: male; F: female; CXR: chest radiograph; ALT: alanine aminotransferase; AST: aspartate aminotransferase; $\gamma$ GT: $\gamma$-glutamyl transpeptidase; VC: vital capacity. 
preceded the systemic manifestations and diagnosis of sarcoidosis by a period ranging 1-16 yrs.

Table 1 describes the nine patients with the initial presentation of uveitis, resulting in the discovery of sarcoidosis. In addition to the asymptomatic chest radiographic changes found in all patients, one had hypercalciuria, two had Heerfordt's disease, and one had a liver impairment. All patients needed corticosteroid therapy, primarily for the uveitis, but also for the above described problems, for a period ranging 2-30 months. The uveitis resolved in all but three chronically affected patients (Nos. 7-9). Two patients (Nos. 2 and 9) had a progression of the chest radiographic changes with exertional dyspnoea, and three patients had unresolved pulmonary mottling for 2 or more years. Two additional cases were classified as having chronic Stage I sarcoidosis. The disease resolved in two patients (Nos. 1 and 6), whilst the remaining seven were diagnosed with chronic sarcoidosis. Symptoms and sarcoid activity declined sufficiently in all patients to avoid further courses of corticosteroid therapy.

The next phase of the study was to define the relationship between uveitis and sarcoidosis in the 13 additional patients in whom uveitis preceded the systemic manifestations of sarcoidosis by a period ranging 1-16 yrs.

In a first group of five patients (all females, 13-42 yrs of age), two presented with anterior bilateral uveitis, and three with posterior monolateral uveitis, resulting in a left visual loss in two patients. The ocular inflammation disappeared without recurrence 6-16 yrs before the appearance of systemic manifestations of chronic sarcoidosis. During this long time period, the patients remained asymptomatic for sarcoidosis. At the time of positive diagnosis for sarcoidosis, the chest radiograph was stage 0 in one patient (only peripheral lymph nodes, no need of therapy), stage I in two, stage II in one, and stage III in one. Three patients required corticosteroid therapy for $1-6$ yrs due to $T \mathrm{~L}, \mathrm{CO}$ impairment ( $\leq 50 \%$ predicted). In October 1994, all patients were stable without therapy, with chest radiographic images remaining unchanged 3-10 yrs after the diagnosis of sarcoidosis. In all of these patients, the relationship between uveitis and sarcoidosis was in doubt or excluded, due to the long ( $\geq 6 \mathrm{yrs}$ ) asymptomatic interval between the two diagnoses.

The final eight patients are described in table 2 . In these patients, uveitis preceded the systemic manifestations by 1-11 yrs. In most cases, the uveitis was chronic (only patient No. 4 was completely cured), and other systemic manifestations of sarcoidosis were present, but unrecognized, before diagnosis. All had eventual pulmonary involvement during the follow-up and, unlike the patients presented in table 1 , most had stage II or III pulmonary sarcoidosis at the time of diagnosis, suggesting a long-standing disease. Patients Nos. 2 and 6-8 had

Table 2. - Uveitis preceding the systemic manifestations of sarcoidosis

\begin{tabular}{|c|c|c|c|c|c|c|c|c|c|c|c|}
\hline \multirow{2}{*}{$\begin{array}{l}\mathrm{Pt} \\
\text { No }\end{array}$} & \multirow{2}{*}{ Sex } & \multirow{2}{*}{$\begin{array}{l}\mathrm{Age}^{+} \\
\text {yrs }\end{array}$} & \multirow{2}{*}{ Uveitis } & \multirow{2}{*}{$\begin{array}{c}\text { Interval }^{\#} \\
\text { yrs }\end{array}$} & \multirow[t]{2}{*}{ Stage* } & \multirow{2}{*}{$\begin{array}{l}\text { Other extra- } \\
\text { pulmonary } \\
\text { manifestations\$ }\end{array}$} & \multirow[t]{2}{*}{ Biopsy } & \multirow{2}{*}{$\begin{array}{l}\text { Prednisone } \\
\text { months }\end{array}$} & \multicolumn{3}{|c|}{ Follow-up after diagnosis } \\
\hline & & & & & & & & & Yrs & Eyes & Others \\
\hline 1 & $\mathrm{~F}$ & 23 & $\begin{array}{l}\text { Anterior, } \\
\text { chronic, left }\end{array}$ & 1 & 0 & $\begin{array}{l}\text { Cervical lymph } \\
\text { nodes }\end{array}$ & $\begin{array}{l}\text { Cervical } \\
\text { lymph node }\end{array}$ & 30 & 3 & $\begin{array}{l}\text { Left } \\
\text { vitreous } \\
\text { opacities }\end{array}$ & $T \mathrm{~L}, \mathrm{CO} 45 \%$ \\
\hline 2 & $\mathrm{~F}$ & 32 & $\begin{array}{l}\text { Posterior, } \\
\text { chronic, } \\
\text { bilateral }\end{array}$ & 4 & $\mathrm{II} \Rightarrow 0$ & $\begin{array}{l}\text { Bilateral groin } \\
\text { lymph nodes }\end{array}$ & $\begin{array}{l}\text { Groin } \\
\text { lymph node }\end{array}$ & 130 & 11 & $\begin{array}{l}\text { Bilateral } \\
\text { posterior } \\
\text { cataract }\end{array}$ & $\begin{array}{l}T \mathrm{~L}, \mathrm{CO} 60 \% \rightarrow 94 \% \\
\text { Recurrent } \\
\text { papulonodular } \\
\text { lesions }\end{array}$ \\
\hline 3 & $\mathrm{~F}$ & 21 & $\begin{array}{l}\text { Anterior, } \\
\text { chronic, } \\
\text { bilateral }\end{array}$ & 10 & $\mathrm{III} \Rightarrow 0$ & $\begin{array}{l}\text { Hypercalciuria } \\
943 \mathrm{mg} \cdot 24 \mathrm{~h}^{-1}\end{array}$ & $\begin{array}{l}\text { Scalene } \\
\text { lymph node }\end{array}$ & 260 & 12 & $\begin{array}{l}\text { Left } \\
\text { cataract } \\
\text { (posterior } \\
\text { and anterior } \\
\text { opacities) }\end{array}$ & $T \mathrm{~L}, \mathrm{CO} 71 \%$ \\
\hline 4 & $\mathrm{~F}$ & 42 & $\begin{array}{l}\text { Anterior, } \\
\text { right, then } \\
\text { anterior, left } \\
\rightarrow \text { visual loss }\end{array}$ & $\begin{array}{ll} & 11 \\
\mathrm{~s} & \\
\mathrm{~s} & \end{array}$ & $\mathrm{II} \Rightarrow \mathrm{III}$ & $\begin{array}{l}\text { Hypercalciuria } \\
402 \mathrm{mg} \cdot 24 \mathrm{~h}^{-1}\end{array}$ & $\begin{array}{l}\text { Pulmonary } \\
\text { (by pleuroscopy) }\end{array}$ & y) 24 & 2 & & $\begin{array}{l}\text { TL,CO } 66 \% \\
\text { TLC } 77 \%\end{array}$ \\
\hline 5 & M & $\begin{array}{l}18 \\
24\end{array}$ & $\begin{array}{l}\text { Anterior left } \\
\text { Posterior, } \\
\text { bilateral }\end{array}$ & 5 & I & $\begin{array}{l}\text { Hypercalciuria } \\
334 \mathrm{mg} \cdot 24 \mathrm{~h}^{-1} \\
\text { Recurrent bilateral } \\
\text { renal stone }\end{array}$ & Mediastinoscopy & y 48 & 4 & & $\begin{array}{l}\text { Recurrent stones } \\
\text { Left } \\
\text { hydronephrosis } \\
T_{\mathrm{L}, \mathrm{CO}} 70 \%\end{array}$ \\
\hline 6 & $\mathrm{~F}$ & 45 & $\begin{array}{l}\text { Posterior, } \\
\text { left, } \\
\rightarrow \text { visual loss }\end{array}$ & s & $\mathrm{III} \Rightarrow 0$ & $\begin{array}{l}1-25(\mathrm{OH})_{2} \mathrm{D}_{3} \\
82.7 \mathrm{pg} \cdot \mathrm{mL}^{-1} \\
\text { (n.v. }<50 \mathrm{pg} \cdot \mathrm{mL}^{-1} \text { ) }\end{array}$ & Open lung & 44 & 12 & $\begin{array}{l}\text { Laser } \\
\text { therapy }\end{array}$ & $\begin{array}{l}\text { Hypercalciuria } \\
\left(332 \mathrm{mg} \cdot 24 \mathrm{~h}^{-1}\right) \\
\text { Osteoporosis } \\
\text { VC } 71 \% \rightarrow 100 \%\end{array}$ \\
\hline 7 & M & 22 & $\begin{array}{l}\text { Anterior, } \\
\text { chronic, left }\end{array}$ & 9 & III & - & Transbronchial & 16 & 2 & & $\begin{array}{l}\text { VC } 67 \% \rightarrow 72 \% \\
T \text { L, Co } 62 \% \rightarrow 81 \%\end{array}$ \\
\hline 8 & M & 40 & $\begin{array}{l}\text { Anterior, } \\
\text { chronic, } \\
\text { bilateral }\end{array}$ & 9 & II & - & Transbronchial & 14 & 6 & $\begin{array}{l}\text { Posterior } \\
\text { bilateral } \\
\text { cataract } \\
\text { Retinal } \\
\text { detachment }\end{array}$ & \\
\hline
\end{tabular}

+: at time of uveitis; \#: between uveitis and diagnosis; *: at the time of diagnosis and during follow-up; \$: at the time of diagnosis. n.v.: normal value; TL,CO: transfer factor of the lungs for carbon monoxide; TLC: total lung capacity. For further definitions see legend to table 1 . 
many relapses of uveitis and respiratory symptoms for 4-9 yrs, before undergoing their first chest radiograph. A similar situation was observed for patient No. 3, who also had recurrent arthralgia and fever during the 10 year interval between uveitis and sarcoidosis diagnosis. Patient No. 4 had a chronic cough and stage II chest radiograph one year after uveitis presentation, and had completed a number of prednisone courses during the $10 \mathrm{yrs}$ prior to reaching our centre where a pulmonary biopsy confirmed the diagnosis of sarcoidosis. Patient No. 5 suffered many renal stones in the 5 year interval between posterior bilateral uveitis and his first chest radiograph. The discovery of a left hydronephrosis subsequently required lithotripsy. The chest radiograph remained normal in patient No. 1 , but her TL,Co dropped to $45 \%$ predicted, and a high resolution computed axial tomography scan showed interstitial lung disease. In addition to eye and lung disease, three patients had hypercalciuria, one had recurrent bilateral renal stones, one had high levels of $1-25(\mathrm{OH})_{2} \mathrm{D}_{3}$; two had peripheral lymph nodes, and one had skin lesions. All required long-term corticosteroid therapy primarily for respiratory function impairment. In October 1994, four patients (Nos. 2-5) were still taking prednisone 5 $\mathrm{mg}$ daily, and will probably always need this therapy. All have chronic disease, even if sarcoid activity is now low, and corticosteroid therapy no longer required for some patients.

Altogether 17 patients were evaluated (tables 1 and 2) in whom uveitis was estimated to be the first recognized manifestation of sarcoidosis. This represents $1.5 \%$ of the total group of 1,156 sarcoidosis patients studied. Assuming a sarcoidosis prevalence of 9 per 100,000 in Italy [27], a prevalence of uveitis plus sarcoidosis of 0.135 per 100,000 can be calculated from the results of this study.

\section{Discussion}

The retrospective study described here has shown that uveitis may precede the diagnosis of sarcoidosis by up to 11 years, even if, in most cases, the diagnosis could have been made sooner with closer attention to patients symptomatology. Ophthalmologists should be aware that any uveitis of unknown origin may be due to sarcoidosis, and that it should be properly investigated with the appropriate diagnostic tests. A previous valuable prospective study by Foster [22] yielded similar results, but the follow-up was limited to only 4 yrs.

In 1989, Sugimoto et al. [28] suggested that T-lymphocytosis, with elevated CD4/CD8 ratio in BAL fluid may be a valid marker in predicting the pulmonary involvement of sarcoidosis in patients with uveitis of unknown origin. They investigated 30 patients with uveitis and a normal chest radiograph: 16 showed bronchoalveolar lymphocytes, with increased CD4/CD8 ratio in 10. Transbronchial biopsy (TBB) was carried out in these 10 patients, with noncaseating granuloma found in four, confirming a subclinical pulmonary involvement. Two other recent brief Japanese reports have shown similar results. In one study [29], TBB confirmed the diagnosis of sarcoidosis in 37 out of 60 patients $(62 \%)$ with suspected ocular sarcoidosis, normal chest radiograph and no apparent extraocular manifestation.
In the second study [30], TBB or scalene biopsy confirmed the diagnosis of sarcoidosis in 98 of 174 similar patients $(57 \%)$. CT then identified lymphadenopathy and/or pulmonary lesions in 43 of them. Because BAL was not easily available in Italian laboratories at the end of the 1970s and beginning of the 1980s, most of the patients did not undergo the BAL test at the time of uveitis presentation. This, as well as the absence of an early chest radiograph in most cases, may explain the delay in diagnosis in a number of patients.

In their white population, Rотноva et al. [23] observed uveitis as the first manifestation of sarcoidosis, with a frequency of 6 out of 69 or $8.7 \%$ which is more than five times higher than that shown in the present study with $1.5 \%$. Whilst the reason for this difference in unclear, the large size of our study population, 1,156, collected from two independent centres, would appear to strengthen the validity of the data.

Most of the patients presented in table 1 and all of those in table 2 had chronic disease in need of long-term corticosteroid therapy. However, in the entire population of 1,156 patients, no more than $30 \%$ were chronic, and no more than $30 \%$ needed corticosteroid therapy. Lupus pernio and bone cysts are recognized markers of sarcoid chronicity [31, 32], and we have recently suggested that renal calculi at presentation may also be a marker of chronicity [33]. The present data suggest that the uveitis preceding the systemic manifestations of sarcoidosis by over one year should be regarded as another marker of chronicity. This is in contrast to uveitis coexisting with other systemic signs at the initial stages of sarcoidosis, when its presentation does not exclude a complete resolution of the disease.

In conclusion, any uveitis of unknown origin should be followed for a potential future diagnosis of sarcoidosis, even if the chest radiograph is normal. Computed tomography, bronchoalveolar lavage, transbronchial biopsy (or Kveim test) and periodic re-evaluations should be carried out over a long period of time when appropriate. Moreover, when uveitis precedes the systemic manifestations of sarcoidosis by over one year, it should be regarded as a marker of chronicity of this disease.

\section{References}

1. British Thoracic and Tuberculosis Association. Geographical variations in the incidence of sarcoidosis in Great Britain: a comparative study of four areas. Tubercle 1969; 50: 211-232.

2. Siltzbach L, James G, Neville E, et al. Course and prognosis of sarcoidosis around the world. Am J Med 1974; 57: 847-852.

3. Scadding J, Mitchell D. First reason for seeking medical advice. In: Scadding J, Mitchell D, eds. Sarcoidosis. 2nd edn. London, Chapman and Hall Medical, 1985; pp. 44-48.

4. Crick R, Pitts Hoyle C, Smellie H. The eyes in sarcoidosis. Br J Ophthalmol 1961; 45: 461-481.

5. Obenauf CD, Shaw HE, Sydnor CF, Klintworth GK. Sarcoidosis and its ophthalmic manifestations. Am J Ophthalmol 1978; 86: 648-655.

6. Iwata K, Namba K, Sobue E, Abe H. Ocular involvement in sarcoidosis. Ann NY Acad Sci 1976; 278: 445-454. 
7. James DG, Neville E, Langley DA. Ocular sarcoidosis. Trans Ophthalmol Soc UK 1976; 96: 113-119.

8. Spalton DJ. Fundus changes in sarcoidosis: review of 33 patients with histological confirmation. Trans Ophthalmol Soc UK 1979; 99: 167-169.

9. Karma A. Ophthalmologische Besonderheiten der Sarkoidose. Klin Mbl Augenheilk 1987; 191: 253-259.

10. Angi MR, Cipriani A, Chilosi M, Ossi E, Semenzato G. Asymptomatic ocular sarcoidosis. Sarcoidosis 1985; 2: 124-134.

11. Graham EM. Differential diagnosis of ocular sarcoidosis. Sarcoidosis 1986; 3: 34-39.

12. Angi MR, DeCaro G, Bergamo L, Scala P, Pucci V, Secchi AG. Low prevalence of uveitis in Italian sarcoidosis patients. Sarcoidosis 1991; 8: 181-182.

13. James DG. Ocular sarcoidosis. Ann NY Acad Sci 1986; 465: 551-563.

14. Takenaka S, Shima K, Fukada K, Tanaka F. A study of S-ACE and BALF in ocular sarcoidosis. Sarcoidosis 1992; 9 (Suppl. 1): 355-356.

15. Jabs DA, Johns CJ. Ocular involvement in chronic sarcoidosis. Am J Ophthalmol 1986; 102: 297-301.

16. Merritt JC, Ballard D, Checkoway H, Mower P, Grimson R. Ocular sarcoidosis: a case-control study among black patients. Ann NY Acad Sci 1986; 465: 619-624.

17. Izumi T. Sarcoidosis in Kyoto. Sarcoidosis 1988; 5: 142-146.

18. Scadding JG, Mitchell DN. Ocular changes. In: Scadding JG, Mitchell DN, eds. Sarcoidosis. London, Chapman and Hall Medical, 1985; pp. 207-226.

19. James DG. Ocular sarcoidosis. Am J Med 1959; 26: 331-339.

20. Karma A. Ophthalmic changes in sarcoidosis. Acta Ophthalmol 1979; 141 (Suppl. 1): 1-94.

21. Scadding JG. Diagnosis of sarcoid uveitis. In: Scadding JG, Mitchell DN, eds. Sarcoidosis. London, Chapman and Hall Medical, 1985; pp. 213-214.
22. Foster S. Ocular manifestations of sarcoidosis preceding systemic manifestations. In: Grassi C, Rizzato G, Pozzi E, eds. Sarcoidosis and Other Granulomatous Disorders. Amsterdam, Elsevier, 1988; pp. 177-181.

23. Rothova A, Alberts C, Glasius E, Kulstra A, Buitenhuis $\mathrm{H}$, Breebaart A. Risk factors for ocular sarcoidosis. Documenta Ophthalmologica 1989; 72: 287-296.

24. Hogan MJ, Kimura SJ, Thygeson P. Signs and symptoms of uveitis. Am J Ophthamol 1959; 47: 155-176.

25. Rizzato G. Sarcoidosis. In: Rakel R, ed. Conn's Current Therapy. Philadelphia, W.B. Saunders, 1987; pp. 157-159.

26. James G, Jones Williams W. Calcium levels. In: James G, Jones Williams W, eds. Sarcoidosis and Other Granulomatous Disorders. Philadelphia, W.B. Saunders, 1985; pp. 163-166.

27. Teirstein AS, Lesser M. Worldwide distribution and epidemiology of sarcoidosis. In: Fanburg BL. Sarcoidosis and Other Granulomatous Diseases of the Lung. New York, Marcel Dekker, 1983; pp. 101-134.

28. Sugimoto M, Nakashima H, Ando M, Kohrogi H, Araki S. Bronchoalveolar lavage studies in uveitis patients without radiological intrathoracic involvement of sarcoidosis. Jpn J Med 1989; 28: 50-54.

29. Ohara K. Is biopsy essential for the diagnosis of ocular sarcoidosis? Sarcoidosis 1995; 12: 164 (Abstract).

30. Ohmichi M, Hiraga Y, Shigahara K, Sasaki H, Shijubo $\mathrm{N}$, Abe S. Diagnosis and laboratory characteristics of ocular sarcoidosis without apparent extraocular lesions. Proceedings of WASOG-BSACI Joint Meeting, London, 15-20 October 1995; 59 (Abstract).

31. James G. Lupus pernio. Lupus 1992; 1: 129-131.

32. James G. Bone. In: James G, Jones Williams W, eds. Sarcoidosis and Other Granulomatous Disorders. Philadelphia, W.B. Saunders, 1985; pp. 134-141.

33. Rizzato G, Fraioli P, Montemurro L. Nephrolithiasis as a presenting feature of chronic sarcoidosis. Thorax 1995; 50: 555-559. 